\title{
Rodzina jako miejsce kontaktów międzypokoleniowych w opinii uczniów szkół ponadgimnazjalnych powiatu cieszyńskiego
}

Streszczenie: Celem tego opracowania jest zwrócenie uwagi na znaczenie, jakie aktualnie przypisują młodzi ludzie oddziaływaniom socjalizacyjno-wychowawczym dziadków. Głównym obszarem rozważań staje się rodzina jako miejsce międzypokoleniowych kontaktów. W celu ukazania szczególnego rodzaju relacji międzygeneracyjnych autorka odwołuje się do wyników badań zespołowych przeprowadzonych na pograniczu polsko-czeskim. Środowisko rodzinne stanowi najważniejszą przestrzeń, w której żyje człowiek, uczestnicząc w jej przetrwaniu, zachowaniu ciągłości i rozwoju. Za Robertem Mertonem autorka przyjmuje rozumienie rodziny jako najważniejszego pasma transmisyjnego, służącego przekazywaniu wzorców kulturowych następnemu pokoleniu.

Słowa kluczowe: socjalizacja, wychowanie, dziadkowie, młodzi ludzie, kontakty międzypokoleniowe, edukacja międzykulturowa

\section{Wprowadzenie}

W związku z dokonującymi się przemianami społecznymi kontakty międzypokoleniowe stanowią istotne zagadnienie. Zmiana stylu życia, kult młodości, dezaktualizacja wiedzy przyczyniają się do zmiany modelu rodziny. W efekcie tych zmian przeobrażeniom ulega pozycja najstarszego pokolenia w rodzinie. W związku z powyższym pragnę zwrócić uwagę na kondycję współczesnej rodziny, relacje interpersonalne między najmłodszym a najstarszym pokoleniem.

W niniejszym opracowaniu podkreślam znaczenie rodziny (Kawula, Brągiel i Jankiel, 2006) jako obszaru doświadczania więzi międzyludzkich zakorzenionych w domu, który gwarantuje poczucie bezpieczeństwa, nienaruszalność panujących obyczajów oraz tradycji, ale i postaw wobec drugiego człowieka.

Szczególną uwagę zwracam na relacje między dziadkami a wnukami (Jas, 2015, ss. 244-259). Zarówno młodzi, jak i starsi są dla siebie oparciem w trudnych chwilach, ostoją bezpieczeństwa, przyjaciółmi, partnerami do rozmów, 
skarbnicą wiedzy. Rola babci i dziadka jest istotna nie tylko dla najmłodszych dzieci w rodzinie, nieco starsze wnuki również potrzebują i często realnie doceniają obecność swoich dziadków. W związku z tym głównym obszarem rozważań staje się rodzina jako miejsce międzypokoleniowej transmisji wartości oraz międzypokoleniowych kontaktów.

\section{Badani i przedsięwzięcie badawcze}

Celem tego opracowania jest zwrócenie uwagi na znaczenie relacji międzypokoleniowej w procesie socjalizacji. W badaniach podjęłam próbę ustalenia odpowiedzi na pytania: Czy młodzi ludzie utrzymują kontakty ze swoimi dziadkami? Czy i w jaki sposób dziadkowie warunkują proces socjalizacyjno-wychowawczy młodych ludzi?

Stawiam tezę, że dziadkowie są obecni w życiu młodzieży, odegrali i nadal odgrywają znaczącą rolę w procesie socjalizacyjno-wychowawczym młodych ludzi. Dziadkowie dla wnucząt są często przewodnikami po życiu norm i wartości, wprowadzają w tajniki tradycji i obyczajów, uczą patriotyzmu oraz przekazują wiedzę na temat życia i świata. Mimo częstych różnic w postrzeganiu rzeczywistości, wynikających z różnicy wieku, dziadkowie bywają wychowawcami swoich wnucząt, dają im poczucie bezpieczeństwa i oparcie w trudnych chwilach. Są ich opiekunami, kiedy rodzice pracują zawodowo. Korzyści z bycia babcią lub dziadkiem są obustronne, ponieważ wnuki zachęcają do podejmowania aktywności fizycznej, motywują do rozwoju intelektualnego oraz są motorem, który napędza do rozwoju pasji i zainteresowań.

W opracowaniu zaprezentowano materiał badawczy pochodzący z badań zespołowych prowadzonych przez pracowników Zakładu Pedagogiki Społecznej i Edukacji Międzykulturowej Wydziału Etnologii i Nauk o Edukacji Uniwersytetu Śląskiego w Cieszynie na Śląsku Cieszyńskim ${ }^{1}$, w ramach projektu nt. Edukacja dzieci, młodzieży i dorosłych w społecznościach zróżnicowanych kulturowo, realizowanego w roku 2016 pod kierunkiem naukowym Aliny Szczurek-Boruty ${ }^{2}$. Zgromadzony materiał badawczy poddany został

1 Śląsk Cieszyński jest krainą historyczną, której obszar - poza granicami powiatu cieszyńskiego - stanowi kilka gmin powiatu bielskiego, zachodnia część miasta Bielska-Białej oraz - po stronie czeskiej - znaczny obszar Kraju Morawsko-Śląskiego.

2 Zespół od lat prowadzi studia w zakresie badania kwestii funkcjonowania młodzieży na Pograniczu. W latach wcześniejszych jego członkowie prowadzili badania pod kierunkiem prof. zw. dra hab. Tadeusza Lewowickiego w ramach prac zespołowych Zakładu Pedagogiki Ogólnej Uniwersytetu Śląskiego, a także Społecznego Ze- 
weryfikacji z wykorzystaniem metod ilościowego i jakościowego opisu badań (Bauman, 1998, s. 56). Prezentowane w tym opracowaniu wyniki badań empirycznych stanowią jego część i odzwierciedlają jedynie analizę ilościową opracowanych kwestii. Badania przeprowadzone zostały w czerwcu 2016 roku w szkołach ponadgimnazjalnych w powiecie cieszyńskim, w takich miejscowościach, jak: Cieszyn, Skoczów, Międzyświeć, Ustroń, Wisła, Istebna. Uczestniczyło w nich 384 uczniów: 173 kobiety i 211 mężczyzn, w tym 287 uczniów szkół technicznych oraz 97 uczniów szkół licealnych. Liczniejszą grupę (232 osoby) stanowiły osoby mieszkające na wsi, a 152 osoby wskazały na miasto jako miejsce zamieszkania. W badaniach dokonano celowego doboru próby, zgodnie z wymogiem, aby była to próba „w maksymalnym stopniu reprezentatywna w stosunku do populacji, z której została pobrana" (Łobocki, 2010, ss. 171-175; Matuszak, 2011, ss. 33-39) (podczas obliczania próby reprezentatywnej posłużono się kalkulatorem doboru próby, uwzględniającym maksymalny błąd 0,05$)^{4}$. Badania przeprowadzone zostały w powiecie cieszyńskim, rozciągającym się wzdłuż granic Polski z Republiką Czeską, a także wzdłuż południowej granicy województwa śląskiego, pokrywającym się terytorialnie - w znacznej mierze - z obszarem Śląska Cieszyńskiego. Historyczną, a zarazem administracyjną stolicą zarówno powiatu, jak i regionu jest najstarsze jego miasto - Cieszyn. Powiat cieszyński to obszar o szczególnej specyfice regionu i zróżnicowaniu kulturowym, będącym wynikiem przenikania się kultur, narodowości, grup etnicznych i wyznaniowych, a także historycznie uwarunkowanej przynależności państwowej (Suchodolska, 1998, ss. 115-131). Historyczne zmiany przynależności państwowej, manifestujące się ma poziomie kulturalnym różnice kulturowe, zgodne wspólistnienie różnych grup wyznaniowych, położenie powiatu cieszyńskiego na ważnych szlakach komunikacyjnych Europy, przyczyniły się do ukształtowania specyficznej tożsamości społecznej mieszkańców, złożonej z kilku rodzajów przynależności (narodowej, językowej, wyznaniowej). Taką tożsamością legitymizuje się także młodzież pogranicza polsko-czeskiego w pasie powiatu

społu Badań Kultury i Oświaty Pogranicza, czego efektem są monografie, opracowania i publikacje książkowe ukazujące się w serii „Edukacja Międzykulturowa”.

3 Zdaniem M. Łobockiego próba składająca się z więcej niż 100 osób stanowi tzw. próbę dużą.

4 W roku szkolnym 2015/2016 w szkołach gimnazjalnych prowadzonych przez powiat cieszyński kształciło się łącznie 4681uczniów (dane uzyskane w Wydziale Edukacji Starostwa Powiatowego w Cieszynie). Posługując się kalkulatorem doboru próby, ustalono grupę reprezentatywną liczącą 355 uczniów. 
cieszyńskiego (Lewowicki, 1994). Na niepowtarzalny charakter ziem Śląska Cieszyńskiego i cieszyńskiego powiatu składają się zatem procesy przenikania i koegzystencji różnych zjawisk, bogactwo tych interakcji kulturowych, dobrze rozwinięte szkolnictwo i wielość ofert kulturalno-oświatowych skierowanych do jego mieszkańców. Wszystko to zachęca do aktywności oraz tworzenia lokalnej społeczności, a także czyni ten obszar atrakcyjnym terenem badawczym (Suchodolska, 2016, ss. 106-108).

\section{Kontakty międzypokoleniowe w opinii uczniów szkół ponadgimnazjalnych}

Wspólnota rodzinna stanowi najważniejszą przestrzeń, w której żyje człowiek, uczestnicząc w jej przetrwaniu, zachowaniu ciągłości i rozwoju. Jakiego rodzaju jest to uczestnictwo w życiu dorosłym zależy właśnie od pierwszych lat życia spędzonych w gronie najbliższych (Nikitorowicz, 1999). To za przyczyną rodziców i dziadków dziecko zostaje łagodnie wprowadzone w kod kulturowy pozwalający mu na komunikację z innymi ludźmi, ale także na odczuwanie wspólnoty i w ten sposób realizację jednej z podstawowych ludzkich potrzeb. „Kontakty rodzinne są jednym z najważniejszych rodzajów stosunków społecznych, w jakich pozostaje człowiek starszy, gdyż często krąg więzów społecznych zacieśnia się do kontaktów z rodziną, które mają ogromne znaczenie dla ludzi w starszym wieku (m.in. stymulują ich aktywność), a także dla pokoleń młodszych - jako czynnik wychowawczy. Człowiek w starszym wieku wnosi bowiem do życia rodzinnego wiele wartości kulturowych, obyczajowych i historycznych, dzieci zaś, przebywając z osobami starszymi, uczą się szacunku dla innych, a także kształtują swoje postawy, poglądy i obyczaje. Członkowie rodziny korzystają z doświadczeń, wiedzy i umiejętności starszego pokolenia. Osoba starsza może być życiowym przewodnikiem i autorytetem dla członków rodziny" (Nikitorowicz, 1999, ss. 59-60).

Środowisko, w którym żyje jednostka, to przede wszystkim środowisko wychowawcze - w nim dokonuje się jej socjalizacja (Tillman, 1996). Przedmiotem badań i analiz są często uwarunkowania procesu socjalizacji, a także jej szczegółowych aspektów, na przykład międzypokoleniowej transmisji wartości dokonującej się w środowisku rodzinnym (Piekarski, 1992; Rostowska, 1995).

Robert Merton twierdzi, że „rodzina jest najważniejszym pasem transmisyjnym, służącym przekazywaniu wzorców kulturowych następnemu pokoleniu" (Merton, 1982, ss. 221-222). W wyniku socjalizacji pierwotnej dziecko przejmuje role i postawy dorosłych, czyli »internalizuje« je i czyni swoimi. 
„Internalizacja jest podstawą - po pierwsze rozumienia innych ludzi oraz po drugie, postrzegania świata jako rzeczywistości znaczącej i jako rzeczywistości społecznej" (Berger i Luckmann, 1983, s. 203). Człowiek zostaje poddany socjalizacji w swoim najbliższym środowisku rodzinnym - mowa wówczas o socjalizacji pierwotnej oraz socjalizacji w środowisku lokalnym. Peter Ludwig Berger i Thomas Luckman twierdzą, że dla jednostki „ważniejsza jest socjalizacja pierwotna oraz że zasadnicza struktura jakiejkolwiek socjalizacji wtórnej musi przypominać strukturę tej pierwszej" (Berger i Luckmann, 1983, s. 9).

Rodzice jako najważniejsi opiekunowie dziecka mają do spełnienia wiele obowiązków związanych z jego wychowaniem, przekazaniem mu odpowiednich umiejętności i kompetencji niezbędnych w dorosłym życiu. Jednak równie ważnymi osobami w procesie socjalizacji dziecka są dziadkowie. Teresa Kukułowicz za dziadków uważa „te osoby, które kształtują u wnuków ich tożsamość rodzinną, regionalną, narodową, przekazują historię swojego życia, podtrzymują kulturę wyrażającą się w pewnych prawdach życiowych, przyczyniają się do zachowania różnych obyczajów w rodzinie, są źródłem rodzinnej informacji, a także moralnego i materialnego oparcia oraz pomocy dzieciom i wnukom" (Kukułowicz, 2006, s. 199).

Wchodzenie w rolę babci lub dziadka to przełomowy moment dla osób starszych; jest to czas radości z pojawienia się nowego członka rodziny, ale moment ten może stać się również czasem konfliktu i nieporozumień. Anna Brzezińska zwraca uwagę, iż podejmowanie roli babci i dziadka ma zawsze swoją lepszą i gorszą stronę. Ta pierwsza to poczucie, iż jest się źródłem miłości i zrozumienia dla wnuków (częściej tak czują babcie) oraz źródłem wiedzy, mądrości i doświadczenia (częściej dotyczy to dziadków). Jest jednak i ciemniejsza strona, gdyż dla wielu ludzi pojawienie się wnuków to kolejny, wyraźny znak ich starzenia się, poza tym między dziadkami i rodzicami mogą pojawić się konflikty związane z metodami wychowania dzieci. Napięcia mogą ujawniać się także wtedy, gdy dochodzi do rozdźwięku pomiędzy oczekiwaniami rodziców oraz samych dzieci a aktywnością babci czy dziadka na polu zawodowym, towarzyskim czy społecznym (Appelt, 2007, ss. 79-95).

Dla poprawności relacji między dziadkami a wnukami duże znaczenie ma charakter kontaktów. Ich częstotliwość uzależniona jest od miejsca zamieszkania, ale mogą na nią mieć również wpływ relacje między dziadkami a ich dziećmi, stan zdrowia oraz wiek dziadków. Ważne są również normy oraz zasady wpajane dzieciom przez ich rodziców, stosunek do dziadków kształtowany jest $\mathrm{u}$ wnucząt na podstawie opinii wyrażanych przez rodziców oraz relacji między dziadkami i ich dziećmi. 
Na uwagę zasługuje fakt, że realne istnienie babci lub dziadka w rodzinie przyczynia się do zdobywania i pogłębiania wiedzy na temat starości i osób starszych przez młodsze pokolenie. Elżbieta Bojanowska twierdzi, że: „wzajemna pomoc i współzależność pokoleń w rodzinie jest najlepszym rozwiązaniem, zarówno dla osób starszych, jak i dla dzieci. Aby człowiek stary był nie tylko przedmiotem troski i opieki, ale cennym źródłem doświadczania i mądrości życiowej" (Bojanowska, 2009, s. 211).

Ostatnie dziesięciolecia przyniosły wiele zmian w funkcjonowaniu współczesnej rodziny, zmianie uległ model rodziny, rodziny nuklearne wyparły rodziny wielopokoleniowe, przez co zmieniła się też pozycja najstarszego pokolenia w rodzinie. Jednak, jak podkreśla Leon Dyczewski, „zmiany modelu rodziny polskiej przybierają nieco inny kształt. Polska w skali Europy charakteryzuje się bowiem bliskimi relacjami międzypokoleniowymi oraz występowaniem dużego odsetka rodzin wielopokoleniowych w skali całego kontynentu. Ponadto zauważa się, iż nawet jeśli pokolenia nie mieszkają pod jednym dachem, to cechują je żywe kontakty i wzajemna pomoc" (Rudnik, 2014, ss. 41-55).

Wykres 1. Deklaracje młodzieży w odniesieniu do wspólnego mieszkania z babcią i/lub dziadkiem (dane podano w procentach)

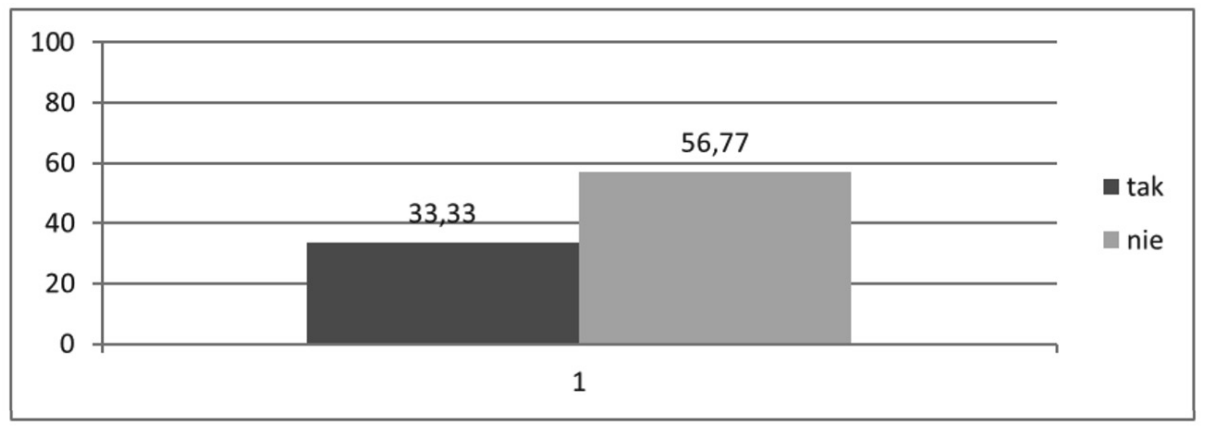

Źródło: badania własne.

Ze swoją babcią i/lub dziadkiem mieszka 33,33\% respondentów, z dziadkami nie mieszka 56,77\% badanych osób. Zwrócić jednak należy uwagę, że $45,31 \%$ badanych wskazuje na bardzo dobre relacje z dziadkami, 35,42\% respondentów deklaruje, że relacje międzypokoleniowe w ich opinii są dobre, tylko 2,08\% ankietowanych oceniało relacje z dziadkami jako bardzo złe, a 1,04\% badanych jako złe. 
Wykres 2. Relacje międzypokoleniowe w opinii uczniów (dane podano w procentach)

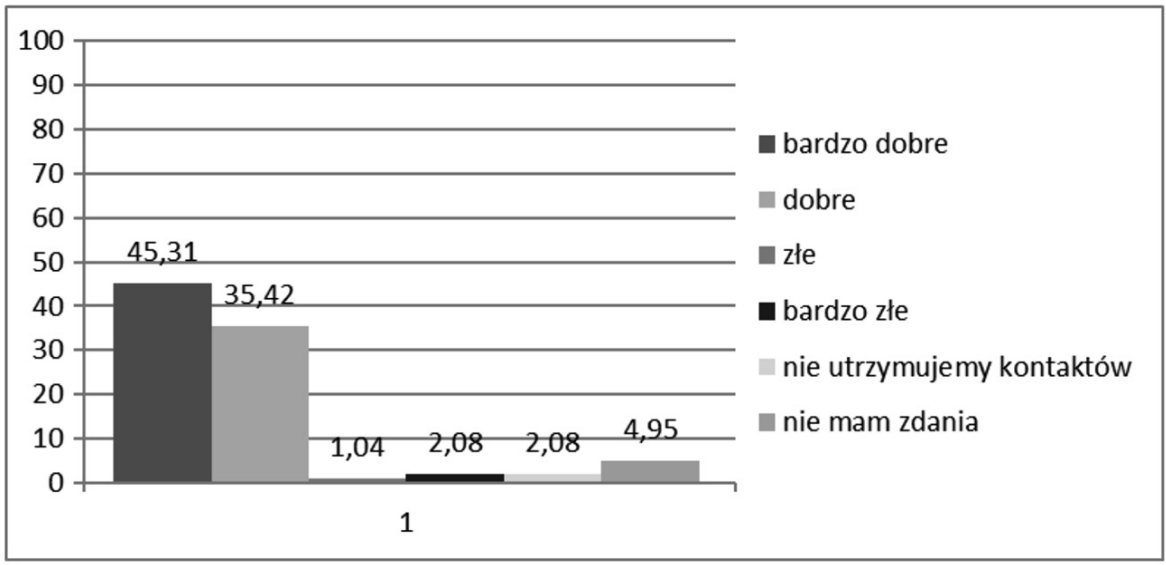

Źródło: badania własne.

Mimo częstych różnic w postrzeganiu rzeczywistości, wynikających z różnicy wieku, dziadkowie bywają wychowawcami swoich wnucząt, dają im poczucie bezpieczeństwa i oparcie. Są ich opiekunami, kiedy rodzice pracują zawodowo. Korzyści z bycia babcią lub dziadkiem są obustronne, ponieważ wnuki zachęcają do podejmowania aktywności fizycznej, motywują do rozwoju intelektualnego oraz są motorem, który napędza do rozwoju pasji i zainteresowań.

„Relacje dziadków z dziećmi i wnukami budują lojalność, zainteresowanie i troskliwość, a także pewnego rodzaju inteligencję emocjonalną i społeczną. Podkreślić należy, że dla wielu starszych osób rodzina (dzieci i wnuki) stanowi źródło siły i wsparcia, daje motywację do działań, zajmuje istotne miejsce w ich życiu" (Zięba-Kołodziej, 2012, ss. 138-139; Wolska-Długosz, 2011, ss. 62-73).

Zaznaczyć należy, że pozytywne relacje między wnukami i dziadkami są istotne zarówno dla młodszego, jak i starszego pokolenia. Wnuki stanowią dla osób starszych źródło radości oraz motywują do aktywnego spędzania czasu wolnego. Dziadkowie pomagają wnukom zrozumieć zachowanie ich rodziców.

Dla wielu starszych osób świadomość bycia potrzebnym swojej rodzinie, mimo zaawansowanego wieku, daje motywację i siłę do dalszego działania.

Fakt ten jest podkreślany w literaturze przedmiotu. „Tam gdzie kontakt wnuków z dziadkami jest bliski, to oni właśnie, bardziej niż rodzice pełnią wo- 
bec wnuków rolę socjalizacji pierwotnej. To starsze pokolenie opisuje i przedstawia świat w szerszym kontekście podczas gdy rodzice (będący partnerami i przyjaciółmi) uczą się razem ze swoimi dziećmi współczesności, dziadkowie odgrywają rolę »mędrców życia «, „stanowią bezpieczną bazę orientacyjną (...) To dziadkowie funkcjonują jako »bastiony bezpieczeństwa « w tym do końca niejasnym, chaotycznym i niepewnym pluralistycznym świecie możliwości i zagrożeń" (Świda-Zięba, 2000, ss. 155-159).

Badane osoby (19,79\%) zadeklarowały, że swoimi dziadkami kontaktują się raz lub kilka razy w tygodniu (16,93\%), tylko 1,04\% badanych wskazał, że ze swoimi dziadkami kontaktuje się codziennie. Kilka razy w roku (6,51\%), raz, dwa razy w roku lub rzadziej (3,39\%) kontaktuje się ze swoimi dziadkami młodzież, która jednocześnie wskazuje na złe lub bardzo złe relacje z dziadkami.

Podkreślić należy, że „prawidłowe relacje rodzinne w okresie wczesnej, a także późnej starości stanowią dla osób starzejących się i starszych podstawę ich prawidłowego funkcjonowania. Pomagają pomyślnie przejść okres adaptacji do życia na emeryturze, odnaleźć swoje miejsce w nowej rzeczywistości, odkryć nowe obszary aktywności, także na płaszczyźnie życia rodzinnego" (Zięba-Kołodziej, 2012, s. 139).

Relacje między dziadkami a wnukami często obalają mity i stereotypy panujące w społeczeństwie na temat starości. Dziadkowie czują się potrzebni, kiedy mogą pozostać w stałych kontaktach ze swoimi najbliższymi, uczestniczyć w realizacji ich planów na przyszłość - „dzieciństwo z dziadkami wpływa na to, jak wnuki jako dorośli będą postępować w stosunku do własnych wnuków" (Brzezińska, Ober-Łopatka i Stec, 2007, s. 87).

Wykres 3. Częstotliwość kontaktów młodzieży z babcią i/lub dziadkiem (dane podano w procentach)

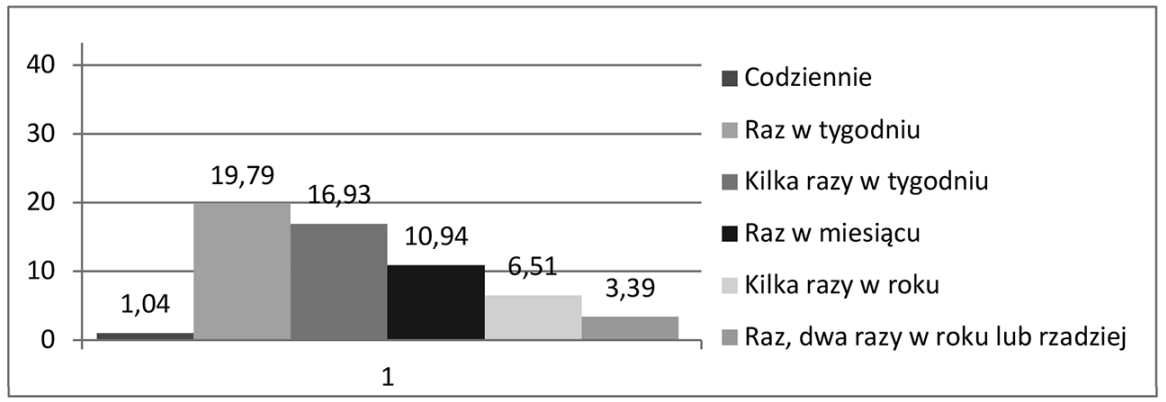

Źródło: badania własne. 
Współpraca tych dwóch generacji przedstawia pokolenie osób w wieku późnej dorosłości jako to, które jest w stanie wiele zaoferować swoim wnukom. Wnuki wprowadzają swoich dziadków w świat nowinek technicznych, natomiast dziadkowie są źródłem doświadczenia i mądrości życiowej. Jak zauważa Barbara Szatur-Jaworska, „każde pokolenie ma prawo do swego stylu życia, zainteresowań, do swego towarzystwa i rozrywek, każde reprezentuje inne wartości i może wiele dać z siebie dla wspólnego dobra" (Szatur-Jaworska, Błędowski i Dzięgielewska, 2006, s. 63). Kontakty międzypokoleniowe zacieśniają relację między młodszym i starszym pokoleniem, stwarzają sytuację, w której człowiek starszy nie musi być nieudolny, schorowany czy zależny od osób trzecich.

Wyniki przeprowadzonych badań wskazują, że pomimo odmiennego postrzegania rzeczywistości młodzi ludzie chętnie podejmują rozmowę ze swoimi dziadkami. 47,4\% respondentów zadeklarowało, że może porozmawiać ze swoimi dziadkami o wszystkim. Codzienne sprawy z dziadkami omawia $45,31 \%$ badanych, o sprawach szkolnych dyskusję podejmuje 30,73\% respondentów. Niewielki odsetek badanych $(1,3 \%)$ rozmawia ze swoimi dziadkami o nowinkach komputerowych, tylko 6,77\% respondentów zadeklarowało, że nie rozmawia ze swoimi dziadkami w ogóle.

Wykres 4. Tematy rozmów między uczniami i ich dziadkami

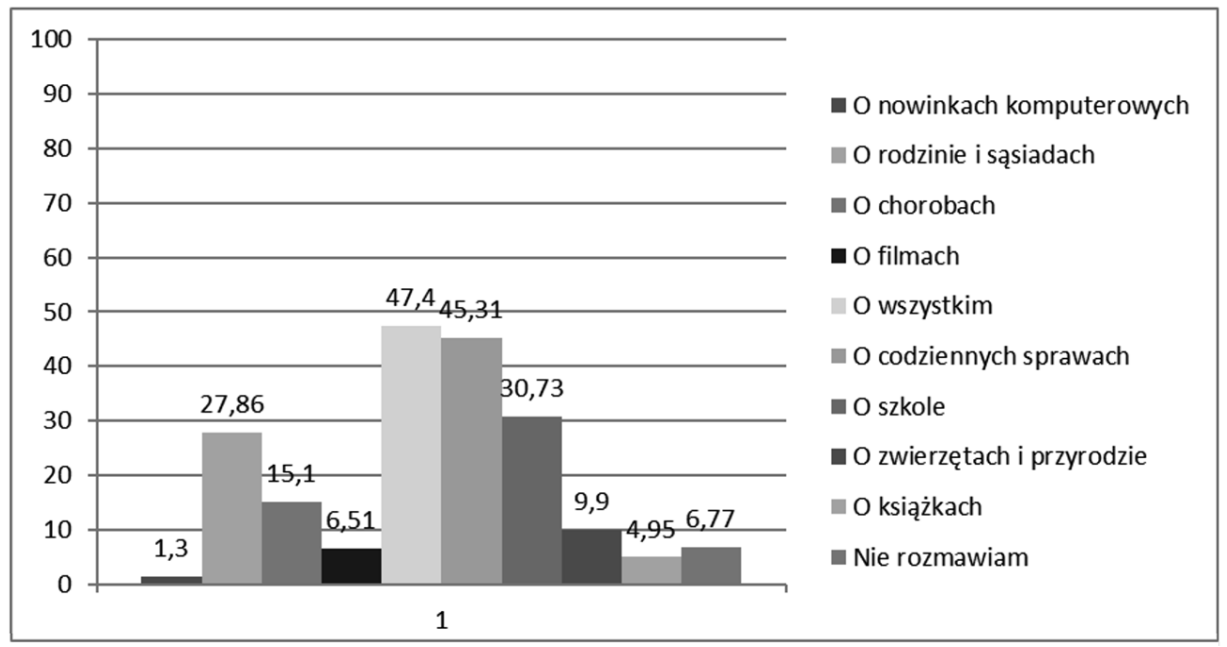

Źródło: badania własne.

Odpowiedzi nie sumują się do 100\% ze względu na wielokrotność wyboru 
Babcia oraz dziadek pełnią w rodzinie różne funkcje, a na szczególną uwagę zasługuje funkcja socjalizacyjno-kulturotwórcza. Jakość doświadczeń i interakcji pomiędzy pokoleniami wpływa na budowanie przez dziecko rozległej wiedzy osobistej na temat stosunków społecznych.

W środowisku rodzinnym zdobywa się umiejętności współdziałania oraz czerpie elementy kultury i świata wartości, „dokonuje się proces enkulturacji dziecka, czyli wprowadzania go do kultury społeczeństwa, w którym będzie żyło" (Twardowski, 1993, s. 41).

Jak twierdzi Teresa Kukołowicz, „dziadkowie kształtują u wnuków ich tożsamość rodzinną, regionalną i narodową, przekazują historię swego życia, podtrzymują kulturę wyrażającą się w pewnych prawdach życiowych, przyczyniają się do zachowania różnych obyczajów rodzinie, są ośrodkiem rodzinnej informacji, a także moralnego i materialnego oparcia oraz pomocy dzieciom i wnukom" (Kukułowicz, 2006, s. 199).

Rodzina stanowi najważniejsze środowisko wychowawcze, przygotowuje najmłodsze pokolenie do wypełniania ról społecznych, kształtuje charakter moralny i przekazuje system wartości.

W opinii uczniów szkół ponadgimnazjalnych największy wpływ na przekazywanie wiedzy na temat tradycji oraz kultury regionu mieli rodzice 50,52\%, jednak niewiele mniej badanych 49,74\% wskazało dziadków jako źródło wiedzy o tradycji i kulturze regionu.

Wykres 5. Osoby odpowiedzialne za przekazywanie tradycji oraz kultury regionu

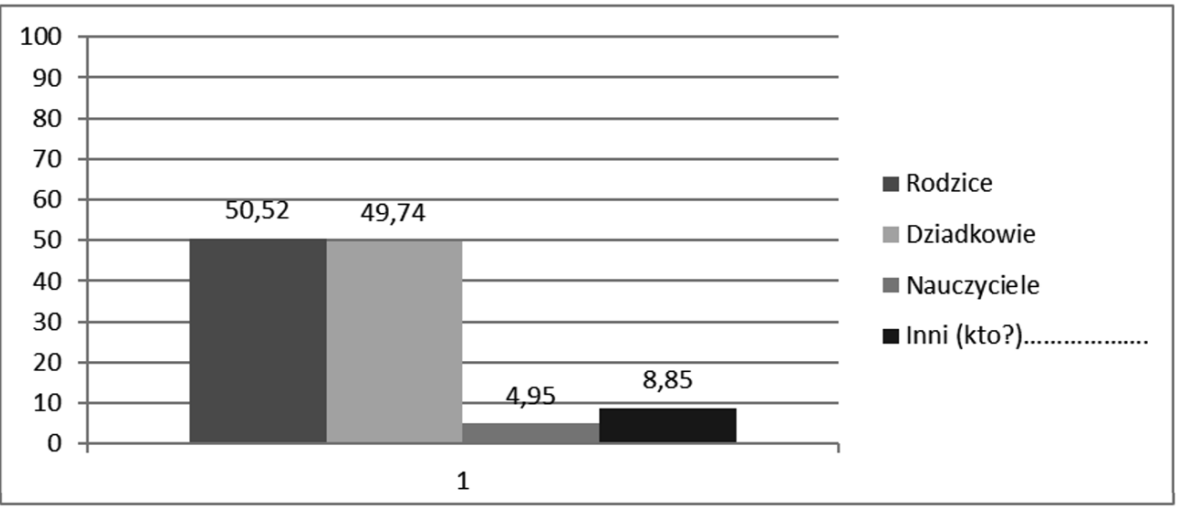

Źródło: badania własne.

Dziadkowie są dla swoich wnucząt nie tylko przekazicielami tradycji, ale również codziennej wiedzy. Przekazują z pokolenia na pokolenia obyczaje, 
zwyczaje, obrzędy, przekonania, zasady, wierzenia, sposoby myślenia, odczuwania lub postępowania, są łącznikiem pomiędzy przeszłością a teraźniejszością. Jak podkreśla Jan Paweł II, „ludzie starzy pomagają nam mądrzej patrzeć na ziemskie wydarzenia, ponieważ dzięki życiowym doświadczeniom zyskali wiedzę i dojrzałość. Są strażnikami pamięci zbiorowej, a więc mają szczególny tytuł, aby być wyrazicielami wspólnych ideałów i wartości, które są podstawą i regułą życia społecznego. Wykluczyć ich ze społeczeństwa znaczy w imię nowoczesności pozbawionej pamięci odrzucić przeszłość, w której zakorzeniona jest teraźniejszość” (Ojciec Święty Jan Paweł II, 1999, s. 21).

\section{Konkluzje}

Celem tego opracowania było zwrócenie uwagi na znaczenie relacji międzypokoleniowej w procesie socjalizacji. Osoby starsze, jako członkowie rodziny, biorą aktywny udział w socjalizacji pierwotnej, przekazują wiedzę, system norm i wartości.

Pozytywne relacje między dziadkami i wnukami przyczyniają się do prawidłowego funkcjonowania całej rodziny. Łatwiej wówczas borykać się z codziennymi problemami, kiedy wśród bliskiej rodziny możemy znaleźć ciepło, spokój oraz wsparcie. Życzliwość ze strony najbliższych: dziadków, rodziców, dzieci wnuków daje wszystkim członkom rodziny bezpieczeństwo. Osoby starsze motywuje do działania, pozwala czuć się potrzebnymi, a co za tym idzie - postępuje proces integracji ich tożsamości.

Przed pedagogiką stają obecnie nowe wyzwania, dotyczące tworzenia sprzyjających warunków rozwoju osobistego, aktywności fizycznej i intelektualnej osób w wieku późnej dorosłości.

Problem relacji międzypokoleniowej oraz udział dziadków w procesie socjalizacyjno-wychowawczym zasługuje na zainteresowanie z konieczności dostrzegania pozycji, potrzeb, pragnień i relacji osób starszych w nowej rzeczywistości rodzinnej.

\section{Bibliografia}

Appelt, K. 2007. Współcześni dziadkowie i ich znaczenie dla rozwoju wnuków. W: Brzezińska, A., Ober-Łopatka K. i Stec, R. i Ziółkowska, K. red. Szanse rozwoju w okresie późnej dorosłości. Poznań: Wydawnictwo Fundacji Humaniora, ss. 79-95. 
Bauman, T. 1998. O możliwości zastosowania metod jakościowych w badaniach pedagogicznych. W: Pilch, T. Zasady badań pedagogicznych. Warszawa: Wydawnictwo Akademickie „Żak”, ss. 54-75.

Berger, P.L. i Luckmann, T. 1983. Społeczne tworzenie rzeczywistości. Warszawa: PIW.

Bojanowska, E. 2009. Opieka nad ludźmi starszymi. W: Szukalski, P. red. To idzie starość. Postawy osób w wieku przedemerytalnym. Warszawa: Raport z badań ZUS, ss. 207-213.

Brzezińska, A.I., Ober-Łopatka, K., Stec, R. i Ziółkowska, K. 2007. Szanse rozwoju w okresie późnej dorosłości. Poznań: Wydawnictwo Fundacji Humaniora.

Jas, K. 2015. Oddziaływania socjalizacyjno-wychowawcze dziadków w rodzinie i ich znaczenie w życiu młodych ludzi. Edukacja Międzykulturowa.4, ss. 244-259.

Kawula, S., Brągiel J. i Janke, A.W. 2006. Pedagogika rodziny. Obszary i panorama problematyki. Toruń: Wydawnictwo Adam Marszałek.

Kukołowicz, T. 2006. Jakim wartościom poświęca się współczesny stary człowiek. W: Steuden, S. i Marczuk, M. red. Starzenie się a satysfakcja żzycia. Lublin: KUL, ss. 197-203.

Lewowicki, T. 1994. Poczucie tożsamości narodowej młodzieży - studium z pogranicza polsko-czeskiego, Cieszyn: Uniwersytet Śląski - Filia w Cieszynie.

List Ojca Świętego Jana Pawła II do osób w podeszłym wieku. 1999. Poznań: Pallottinum.

Łobocki, M. 2010. Wprowadzenie do metodologii badań pedagogicznych. Kraków: Oficyna Wydawnicza „Impuls”.

Matuszak, A. i Matuszak, Z. 2011. Celowy dobór próby. General and Profesional Education. 2, ss. 33-39.

Merton, R.K. 1982. Teoria socjologiczna i struktura spoteczna. Warszawa: PWN.

Nikitorowicz, J. 1999. Szanse i zagrożenia tożsamości rodzinnej. W: Nikitorowicz, J. red. Rodzina wobec wyzwań w edukacji międzykulturowej. Białystok: Wydawnictwo Uniwersyteckie „Trans Humana”, ss. 66-78.

Piekarski, J. 1995. Międzypokoleniowa transmisja wartości w środowisku rodzinnym małego miasta. Wychowawcze studium relacji międzygeneracyjnych. Łódź: Uniwersytet Łódzki.

Rostowska, T. 1995. Transmisja międzypokoleniowa $w$ rodzinie $w$ zakresie wybranych wymiarów osobowości. Łódź: Uniwersytet Łódzki. 
Rudnik, A. 2014. Relacje międzypokoleniowe w rodzinie - perspektywa gerontologiczna. W: Szukalski, P. red. Relacje międzypokoleniowe we wspótczesnych polskich rodzinach. Łódź: UŁ, ss. 41-55.

Suchodolska, J. 1998. Cieszyn - miasto Pogranicza. Potencjał społeczno-kulturowy. W: Jasiński, Z., Lewowicki, T. i Nikitorowicz, J. red. Potencjat społeczno-kulturowy polskich pograniczy. Opole: Uniwersytet Opolski, ss. 115-131.

Suchodolska, J. 2016. Kryzys w rozwoju psychospołecznym młodzieży - potrzeba wsparcia rodzinnego i środowiskowego. W: Szczurek-Boruta, A., Chojnacka-Synaszko, B. i Gancarz, A. Szkoła i rodzina w środowisku lokalnym - teoria i praktyka. Toruń: Wydawnictwo Adam Marszałek, ss. 101-113.

Szatur-Jaworska, B., Błędowski, P. i Dzięgielewska, M. 2006. Podstawy gerontologii spotecznej. Warszawa: Wyd. Aspra-JR.

Świda-Ziemba, H. 2000. Młodzież końca tysiaclecia. Obszar świata i bycia w świecie. Warszawa: ISNS UW.

Tillmann, K. J. 1996. Teorie socjalizacji. Społeczność-instytucja-upodmiotowienie. Warszawa: PWN.

Twardowski, A. 1993. Rodzina jako środowisko edukacyjno-kulturowe. W: Jankowski, D. red. Edukacja kulturalna. Szkoła i rodzina. Kalisz: Wojewódzki Ośrodek Metodyczny w Kaliszu, ss. 41-57.

Wolska-Długosz, M. 2011. Rola babć i dziadków we współczesnych rodzinach polskich. W: Matyjas, B. i Gościniewicz, M. red. Człowiek stary w rodzinie - o trudnym problemie przemocy wobec starszych. Kielce: Uniwersytet Humanistyczno-Przyrodniczy Jana Kochanowskiego w Kielcach, ss. 62$-73$.

Zięba-Kołodziej, B. 2012. Rola dziadków w życiu rodziny. W: Seredyńska, D. red. Uczestnictwo społeczne w średniej i późnej dorosłości. Bydgoszcz: Wydawnictwo Uniwersytetu Kazimierza Wielkiego, ss. 136-152.

\section{Family as a place of contacts across generations in the opinions of learners from upper-secondary schools in Cieszyn County}

Abstract: The aim of this research paper is paying attention to the meaning which young people currently attribute to the socializational and educational influence of grandparents. The main area of the dissertation becomes a family as a place of intergenerational contacts. In order to present special type of intergenerational 
relations the author refers to the results of group research conducted in Cieszyn district. The family environment constitutes the most crucial space in which a human being lives, participating in its survival, maintaining its continuity and development. After Robert Merton the author defines a family as the most important transmitting stream used for passing cultural patterns down to the next generations.

Keywords: family, socialization, upbringing, grandparents, young people, intergenerational contacts, intercultural eduacation

Translated by Katarzyna Jas 